\title{
Profil Darah Sapi Bali Yang Mendapat Konsentrat Berbahan Semak Bunga Putih (Chromolaena odorata) Dengan Level Yang Berbeda
}

\section{Gerson F. Bira}

Fakultas Pertanian, Universitas Timor, Kefamenanu, TTU - NTT, 85613, Indonesia.

\section{Article Info}

Article history:

Received 10 Januari 2016

Received in revised form 25 Mei 2016

Accepted 17 Juni 2016

\section{Keywords:}

Profil darah, sapi bali, semak bunga putih,

level yang berbeda.

\begin{abstract}
Abstrak
Penelitian ini bertujuan untuk melihat profil darah ternak sapi penggemukan yang mendapat chromolaena odorata (Co) dalam konsentrat. Materi yang digunakan adalah 4 ekor sapi Bali jantan muda yang berumur 2 tahun dengan rerata berat badan awal $143 \mathrm{~kg}( \pm$ $7,11 \mathrm{Kg}$ ). Penelitian ini menggunakan rancangan percobaan bujur sangkar latin (4 x 4) dipakai untuk menguji 4 jenis ransum perlakuan Ransum yang diuji adalah mash yang mengandung COM10\% (COM 10\%), 20\% (COM 20\%), 30\% (COM 30\%) dan 40\% (COM 40\%) Konsentrat diberikan $2 \%$ dari berat badan. Parameter yang diamati adalah glukosa darah, urea darah, Hb, eritrosit dan trombosit darah. Hasil menunjukkan bahwa setiap penambahan Co dalam pakan tidak mempengaruhi profil darah ternak percobaan (normal), hal ini menunjukkan bahwa dengan perlakuan fisik akan megurangi bahkan menghilangkan kandungan anti-nutrient yang dikandung $C o$. Disimpulkan bahwa penggunaan Co dalam kosentrat sampai 40\% tidak akan mempengaruhi profil darah ternak sapi penggemukan sehingga $C o$ berpotensi untuk dimanfaatkan sebagai bahan pakan sumber protein yang murah dan mudah untuk didapatkan. (O2016 dipublikasikan oleh JAS
\end{abstract}

\section{Pendahuluan}

Chromolaena odorata (Co) telah menjadi musuh besar para petani dan peternak hampir di setiap kawasan wilayah Indonesia tanpa terkecuali kawasan lahan kering NTT karena memiliki sifat tumbuh dan laju penyebarannya yang sangat cepat. Tanaman ini memiliki potensi besar dalam peningkatan produks pertanian dan peternakan. Co memiliki kandungan nitrogen $3,36 \%$ setara dengan protein kasar $21 \%$ bahkan pada daun muda nitrogennya dapat mencapai 5,6\% (Mullik, 2002; Ndun, 2001), memiliki komposisi mineral dan kandungan asam amino yang baik bagi ternak (Ikhimioya, 2007; Fasuyi dkk., 2005) dan produksi biomasa Co mencapai 70 ton bk/ha/thn. Keseimbangan asam amino Co baik untuk ternak monogastrik, degradabilitas efektif dalam rumen $>80 \%$, dan palatabilitasnya lebih baik dari gamal. Namun, penggunaannya sebagai pakan terhambat karena kandungan antinutrisi yang dikandungnya ; haemagglutinnin, oxalate, phytic acid dan saponin (Ikhimioya dkk.,2007) yang dapat menghambat produksi ternak (penggumpalan sel darah merah, bersifat toksis, menurunkan kelarutan mineral, menghambat kerja enzim proteolitik). Kecukupan nutrisi ternak dapat dilihat dari fungsi fisiologisnya. Bila kebutuhan nutrisi tercukupi, fungsi fisiologis berjalan normal. Namun bila tidak tercukupi, maka kemungkinan fungsi fisiologis ternak akan terganggu, fungsi fisiologis ternak dapat diamati melalui kadar metabolit darah.

\section{Metode}

Penelitian ini menggunakan 4 ekor sapi bali jantan muda yang berumur 2 tahun (rata-rata berat badan awal $143 \mathrm{~kg}$ ). Menggunakan rancangan percobaan bujur sangkar latin ( $4 \mathrm{x} 4)$ dipakai untuk menguji 4 jenis ransum perlakuan. Ransum yang diuji adalah mash yang mengandung Co; COM10\% (COM 10\%), $20 \%$ (COM 20\%), 30\% (COM 30\%) dan 40\% (COM 40\%). Konsentrat diberikan $2 \%$ dari berat badan. Penambahan pakan disesuaikan untuk setiap periode berdasarkan berat badan yang dicatat pada setiap akhir periode pengambilan data. Pakan basal (hay rumput kume) dan air minum diberikan secara ad libitum. Ransum disusun secara iso-protein (18\%) dan EM (12MJ) disemua level untuk memperoleh berat badan $0,8 \mathrm{~kg} / \mathrm{ekor} / \mathrm{hari}$. Setiap periode berlangsung selama 15 hari (10 hari adaptasi dan 5 hari pengumpulan data) Sampel darah diambil melalui vena jugularis sebanyak $10 \mathrm{ml}$ menggunakan spuit ukuran $10 \mathrm{ml}$, dimasukkan ke dalam tabung darah yang berisi lithium heparin 125 IU pada setiap akhir periode penelitian. Glukosa darah diukur menggunakan alat spektrofotometer, kadar urea darah ditentukan dengan menggunakan reaksi Barthelot, kadar haemoglobin $(\mathrm{Hb})$ menggunakan kertas skala haemoglobin, perhitungan sel darah merah dilakukan menurut petunjuk Swenson (1984) sedangkan trombosit darah dihitung dengan metode secara langsung menggunakan kamar hitung yaitu dengan mikroskop fase kontras dan mikroskop cahaya (Rees-Ecker).

\section{Tabel 1. Komposisi Ransum Penelitian}

\begin{tabular}{lllll}
\hline \multirow{2}{*}{ Bahan Pakan } & \multicolumn{4}{c}{ Level Perlakuan (\%) } \\
& $\mathbf{1 0}$ & $\mathbf{2 0}$ & $\mathbf{3 0}$ & $\mathbf{4 0}$ \\
\hline Chromolaena odorat (\%) & 10 & 20 & 30 & 40 \\
Tepung Lamtoro (\%) & 30 & 20 & 10 & 0 \\
Jagung Kuning (\%) & 30 & 30 & 30 & 30 \\
Dedak Padi (\%) & 20 & 19,87 & 19,75 & 19,6 \\
Tepung Ikan (\%) & 5 & 5 & 5 & 5 \\
Urea (\%) & 3 & 3,13 & 3,25 & 3,4 \\
Mineral Mix (\%) & 2 & 2 & 2 & 2 \\
\hline
\end{tabular}

Tabel 2. Komposisi Nutrisi Bahan Pakan Penelitian

\begin{tabular}{llcccccc}
\hline $\begin{array}{l}\text { No } \\
\cdot\end{array}$ & Bahan Pakan & $\begin{array}{c}\mathrm{BK} \\
(\mathrm{g} / \mathrm{kg})\end{array}$ & $\begin{array}{c}\mathrm{BO} \\
(\mathrm{g} / \mathrm{kg})\end{array}$ & $\begin{array}{c}\mathrm{PK} \\
(\mathrm{g} / \mathrm{kg})\end{array}$ & $\begin{array}{c}\mathrm{LK} \\
(\mathrm{g} / \mathrm{kg})\end{array}$ & $\begin{array}{c}\text { Total } \\
\mathrm{CHO}\end{array}$ & $\begin{array}{c}\text { EM } \\
(\mathrm{MJ} / \mathrm{kg} \\
\mathrm{BK})\end{array}$ \\
\hline 1 & $\begin{array}{l}\text { Hay rumput kume } \\
2\end{array}$ & 850 & 900 & 50,0 & 4 & 850 & 10,34 \\
2 & $\begin{array}{l}\text { Chromolaena } \\
\text { odorata }\end{array}$ & 310 & 890 & 210 & 110 & 570 & 11,41 \\
3 & Tepung lamtoro & 320 & 910 & 244,0 & 126 & 540 & 12,71 \\
4 & Jagung kuning & 860 & 935 & 102 & 40 & 793 & 10,61 \\
5 & Tepung ikan & 930 & 900 & 694 & 91 & 115 & - \\
6 & Urea & 950 & - & 2600 & - & - & - \\
7 & Mineral mix & 960 & - & - & - & - & - \\
\hline
\end{tabular}

Sumber: Mullik, 2002

\section{Hasil dan Pembahasan}

Kecukupan nutrisi ternak dapat dilihat dari fungsi fisiologisnya. Namun bila tidak tercukupi, maka kemungkinan fungsi fisiologis ternak akan terganggu, fungsi fisiologis ternak dapat diamati melalui kadar metabolit darah.

Tabel 3. Profil darah ternak perlakuan yang diberikan mash dengan kandungan Chromolaena odorata Sebesar 10\% (COM10), 20\% (COM20), 30\% (COM30) dan 40\% (COM40) sebanyak $2 \%$ dari berat badan

\begin{tabular}{lllll} 
Parameter & COM10 & COM20 & COM30 & COM40 \\
\hline Glukosa (mg/dL) & 83,87 & 82,51 & 82,39 & 81,13 \\
Urea $(\mathrm{mg} / \mathrm{dL})$ & 52,07 & 51,26 & 50,66 & 52,42 \\
$\mathrm{Hb}(\mathrm{g} / \mathrm{dL})$ & 12,00 & 10,64 & 11,02 & 12,00 \\
Eritrosit $(\mathrm{ml})$ & $13,5 \times 10^{6}$ & $10,7 \times 10^{6}$ & $12,1 \times 10^{6}$ & $14,5 \times 10^{6}$ \\
Trombosit $(\mathrm{ml})$ & $25,7 \times 10^{4}$ & $30,6 \times 10^{4}$ & $27,3 \times 10^{4}$ & $24,6 \times 10^{4}$ \\
\hline
\end{tabular}

Dari Tabel 3 menggambarkan bahwa glukosa darah, urea darah, $\mathrm{Hb}$, eritrosit dan trombosit tidak menunjukkan perbedaan yang signifikan. Hal ini berarti peningkatan level Co dalam konsentrat (COM10-COM40) yang disumbangkan mash tidak memberikan efek yang negatif terhadap metabolit darah sebab kompisisi nutrisi pakan tersusun secara iso-nitrogenous dan isoenergi sehingga nutrisi yang diserap oleh tubuh ternak dalam proses metabolisme berjalan dengan normal.

Rata-rata kadar Glukosa darah pada ternak yang mendapat konsentrat (COM10-COM40) berkisar 81,13-83,87 (mg/dL), ini masih pada kisaran glukosa darah normal pada sapi, Mitruka dkk. (1977) melaporkan kadar glukosa darah sapi yang normal berada pada kisaran 43 - $100 \mathrm{mg} / \mathrm{dL}$. Hal ini menggambarkan bahwa konsentrat yang mengandung Co terserap secara baik dalam proses metabolisme karbohidrat yang kemudian hasilnya akan disimpan dalam bentuk glikogen yang merupakan karbohidrat penyimpan energi yang terdiri dari unit-unit glukosa. Sapi akan menjadi lemah bila energi tidak mencukupi dalam darah atau hipoglikemia yang dapat terjadi pada sapi yang kurang pakan. Kadar glukosa dalam darah adalah yang merefleksikan sumber energi dalam tubuh.

Rata-rata kadar urea darah (Tabel 3) menunjukkan bahwa semakin tinggi level Co dalam pakan akan menurunkan kadar urea darah. Hal ini disebabkan oleh tingginya pemakaian $\mathrm{NH}_{3}$ rumen dan semakin meningkatnya populasi bakteri yang memanfaatkan zat-zat gizi bagi perkembangbiakannya sehingga jumlah amonia dapat dimanfaatkan untuk menyusun protein tubuh mikroba rumen itu sendiri. Ditambah lagi dengan kandungan protein pakan (18\%) dirombak kemudian mengalir dalam tubuh dari hasil sampingan metabolisme protein. 
$\mathrm{Hb}$ merupakan suatu protein yang mengandung senyawa besi hemin dan mempunyai fungsi mengikat oksigen di paru-paru dan mengedarkan keseluruh jaringan tubuh sehingga dapat dikatakan bahwa di paru-paru terjadi reaksi antara haemoglobin dan oksigen. Kadar $\mathrm{Hb}$ darah sapi dalam penelitian ini adalah 10,64-12,00 (g/dL). Schalm dkk. (1975) menyatakan bahwa kadar normal $\mathrm{Hb}$ darah pada sapi berkisar 8-16 g/dL atau rata-rata $12 \mathrm{~g} / \mathrm{dL}$ sedangkan Coles (1980) melaporkan bahwa $\mathrm{Hb}$ darah normal pada sapi bali berkisar 8,5$5,7 \mathrm{~g} / \mathrm{dL}$.

Eritrosit terdiri dari air 65\%, $\mathrm{Hb} 33 \%$, dan sisanya adalah sel stoma lemak, mineral, vitamin, dan bahan organik lainnya serta ion K (Kusumawati, 2004). Fungsi utamanya adalah adalah mengangkut haemoglobin dan juga mengangkut oksigen dari paru-paru keseluruh jaringan tubuh. Apabila eritrosit di bawah kisaran normal maka ternak mengalami anemia (Utama, 2001). Hal tersebut disebabkan nutrisi yang kurang memadai sehingga pembentukan darah kurang baik. Rataan kadar eritrosit darah pada pada Tabel 3 yakni $10,7 \times 10^{6} \mathrm{ml}$ $-14,5 \times 10^{6} \mathrm{ml}$. Pada penelitian ini jumlah eritrosit sedikit lebih tinggi dari jumlah normalnya yakni 7,5 x $10^{6}$ (Coles, 1980). Hal ini mengidikasikan bahwa konsentrat yang diberikan mampu menyediakan protein yang kemudian menghasilkan produk berupa asam amino yang diserap oleh dinding usus serta diedarkan keseluruh tubuh oleh darah yang kemudian protein tersebut larut dalam darah sehingga dapat digunakan dalam pembentukan eritrosit. Demikian juga penambahan urea dalam konsentrat yang dapat menambah protein yang digunakan eritrosit sehingga penambahan urea dapat mempengaruhi jumlah eritrosit yang digunakan. Tingginya eritrosit tidak memberikan efek negatif bagi pertumbuhan ternak.

Fungsi utama trombosit adalah pembentukan sumbat mekanik selama respon hemostasis normal terhadap cedera vascular. Tanpa trombosit, dapat terjadi kebocoran darah spontan melalui pembuluh darah kecil. Dari penelitian ini menunjukkan bahwa jumlah trombosit ternak sebagai akibat dari penggunaan Co dalam konsentrat yakni berkisar antara 24,6 x $10^{4}-30,6 \times 10^{4}$. Untuk dapat terjadi hemostasis primer yang normal dan trombosit memenuhi tugasnya membentuk sumbat trombosit inisial, maka harus terdapat trombosit dalam jumlah memadai di dalam sirkulasi, dan trombosit tesebut harus berfungsi normal. Jumlah trombosit ini masih dalam kisaran normal sapi (Swenson, 1984). Keseimbangan nutrien dapat meningkatkan sistem kekebalan untuk menyerang bakteri patogen.

\section{Simpulan}

Disimpulkan bahwa $\mathrm{Co}$ berpotensi untuk digunakan dalam konsentrat sebagai sumber protein yang murah dan mudah didapatkan sampai level $40 \%$. Walaupun mengandung anti nutrisi yang bersifat menghambat pertumbuhan namun perlakuan fisik yang diberikan dalam pembuatan mash (pemotongan, pengeringan dan penepungan) dapat mengurangi dan menghilangkan kandungan anti nutrisinya. Hal ini dapat dibuktikan dari fungsi fisiologis ternak (metabolit darah) pada penelitian ini.

\section{Pustaka}

Coles, EH. 1980. Veterinary Clinical Pathology. 3rd Ed. WP Sanders CA Philadelphia, London,Toronto.

Fasuyi, A. O., Fajemelihen, K.S.O. dan Oro, S. O. 2005. Nutritional potentials of siam weed (chromolaena odorata) leaf meal on laying hens. biochemical and haemtological implications. Pakistan journal of nutrition 4 (5): 336-341.

Ikhimoya, I., Bamikole. M.A., Omoregie. A.U., and Ikhatua. U.J. 2007. Compositional Evaluation of Some Dry Season Shrub and Tree Foliages in a Transitionally Vegetated Zone of Nigeria. Livestock Research for Rural Development Vol 19 (3), pp 1-9.

Kusumawati, D. 2004. Bersahabat Dengan Hewan Coba. Gadjah Mada Press.Yogyakarta.

Mitruka. B.M.,H. M.Rawnsley, and B.V.Vadehra.1977. Clinical Biochemical and Hematological Reference Values in Normal Experimental Animals. Mass on Publishing, Inc.New York

Mullik, M.L. 2002. Laporan penelitian: Strategi Pemanfaatan Semak Bunga Putih (Chromolaena odorata) untuk Meningkatkan Produksi Ternak dan Pendapatan Peternak di Daerah Lahan Kering. Kerjasama Fakultas Peternakan Universitas Nusa Cendana dan Kementrian Riset dan Teknologi Republik Indonesia melalui Riset Pengembangan Kapasitas.

Ndun, M.L. 2001. Degradabilitas Bahan Kering, Bahan Organik, dan Protein Kasar Chromolaena odorata. Skripsi. Fakultas Peternakan Universitas Nusa Cendana

Schalm, OW, NC Jain \& EJ Carroll, 1975, Veterinary Haematology, 3 rd ed, Lea and Febinger

Swenson, M.J.1984. Dukes Physiologi of Domestic Animals, 10 ${ }^{\text {th }}$ ed. Ithaca. Cornel University Press.

Utama, I.H. 2001. Karakteristik Anemia Sapi Bali. Jurnal Veteriner. Fakultas Kedokteran Hewan, Unud. Vol. 2, No. 1 : 13-6. Denpasar

Sufiriyanto, Indraji, M., 2005. Uji In Vitro dan In Vivo Ekstrak Campuran Mengkudu (Morinda citrifolia) dan Bawang Putih (Allium sativum) pada Sapi Perah Penderita Mastitis Sub Klinis. J Anim. Prod. 7, 101-105.
Usha, R., Sangeetha, S., Palaniswamy, P., 2010. Antimicrobial Activity of Rarely Known Species, Morinda citrifolia. LEthnobotanical Leafl. 14:30611 . 